\begin{tabular}{|c|c|}
\hline $\begin{array}{l}\text { 2. To: (Receiving Organization) } \\
\text { Technical Operations }\end{array}$ & $\begin{array}{l}\text { 3. From: (originating Organization) } \\
\text { Process Engineering }\end{array}$ \\
\hline $\begin{array}{l}\text { 5. Proj./Prog./Dept./Div.: } \\
\text { Spent Nuclear Fuel Project }\end{array}$ & $\begin{array}{l}\text { 6. Design Authority/ Design Agent/Cog } \\
\text { Engr.: } \\
\text { R. A. Sexton }\end{array}$ \\
\hline
\end{tabular}

8. Originator Remarks:

For release

11. Receiver Remarks: 11A. Design Baseline Document? [] Yes [X] No

4. Related EDT No.:

$\mathrm{N} / \mathrm{A}$

7. Purchase Order No.:

N/A

9. Equip./Component Ho.:

N/A

10. System/Bldg./Facility:

N/A

12. Major Assm. Dwg. No.:

N/A

13. Permit/Permit Application No.: N/A

14. Required Response Date: $N / A$

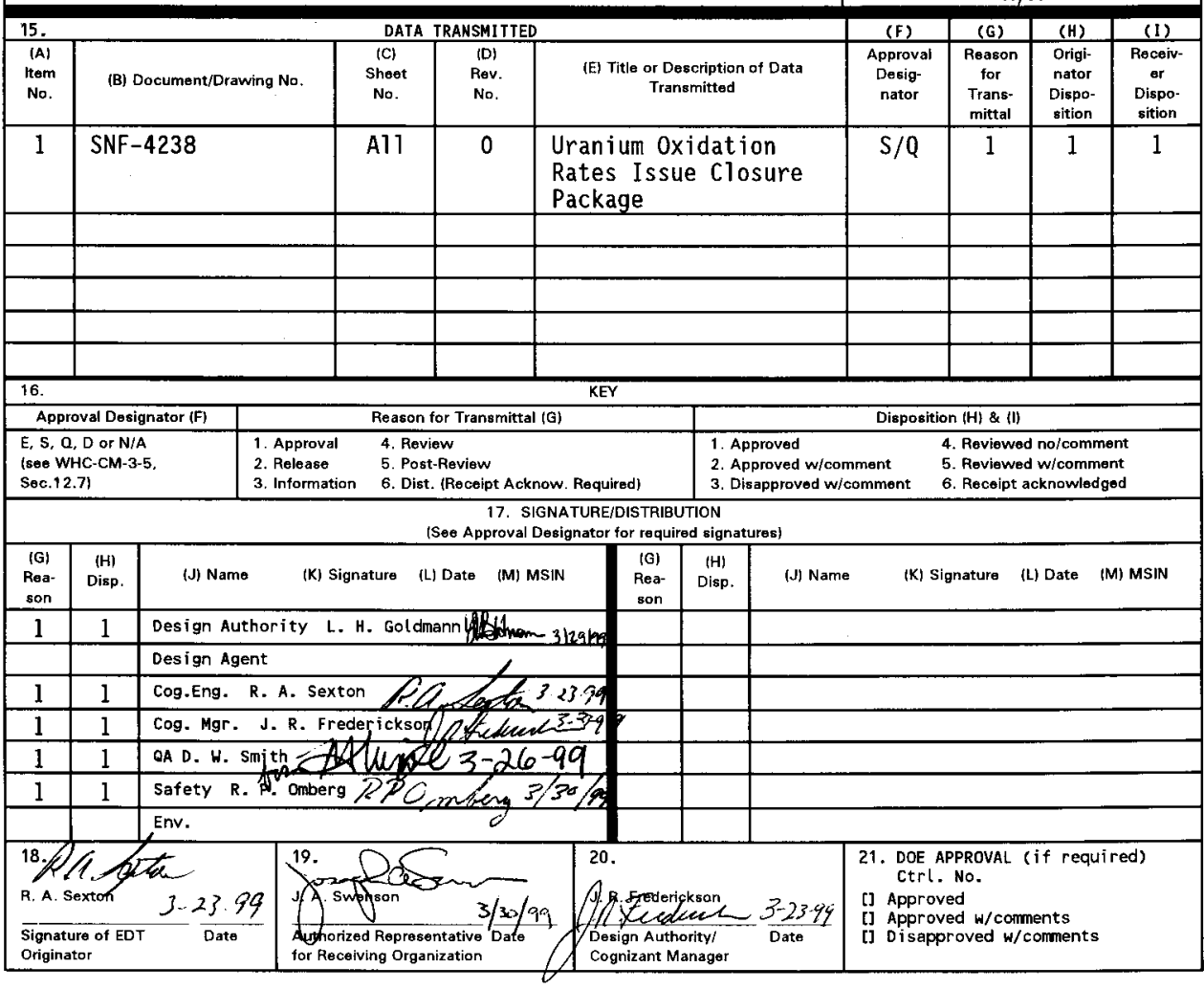

BD-7400-172-2(05/96) GEF097 


\section{URANIUM OXIDATION RATES ISSUE CLOSURE PACKAGE}

\section{R. A. Sexton*}

DE\&S Hanford, Inc., Richland, WA 99352

U.S. Department of Energy Contract DE-AC05-96RL13200

$\begin{array}{lll}\text { EDT/ECN: } & 625820 & \text { UC: } 510 \\ \text { Org Code: } & 2 F 300 & \text { Charge Code: } 105355 \\ \text { B\&R Code: } & \text { EW704000 } & \text { Total Pages: } 8\end{array}$

Key Words: Uranium 0xidation Rates, Spent Nuclear Fuel, Technical Issue Closure

Abstract: An assessment of all relevant uranium reaction rate data, including the most recently completed laboratory studies in moist inert gas, confirms that the correlations and enhancement factor already documented in the SNF Project Technical Databook are appropriately conservative.

Uranium oxidation rates under the varying conditions in the MCO are important in modeling heat generation, gas composition, and particulate generation in the MCO. These reaction rates are used in SNF Project safety basis calculations. Uranium reaction rate data from studies of spent $\mathrm{N}$ reactor fuel were used to confirm reaction rate correlations which were derived from literature data and used in system design for the SNF Project. A rate enhancement factor is used with these correlations to account for uncertainty associated with the data and the potential for spent $N$ Reactor fuel having characteristics that differ from uranium represented in the 1 iterature data.

*Technical Resources International, Inc., Richland, WA.

TRADEMARK DISCLAIMER. Reference herein to any specific commercial product, process, or service by trade name, trademark, manufacturer, or otherwise, does not necessarily constitute or imply its endorsement, recommendation, or favoring by the United States Government or any agency thereof or its contractors or subcontractors.

Printed in the United States of America. To obtain copies of this document, contact: Document Control Services, P.O. Box 950, Mailstop H6-08, Richland WA 99352, Phone (509) 372-2420; Fax (509) 376-4989.
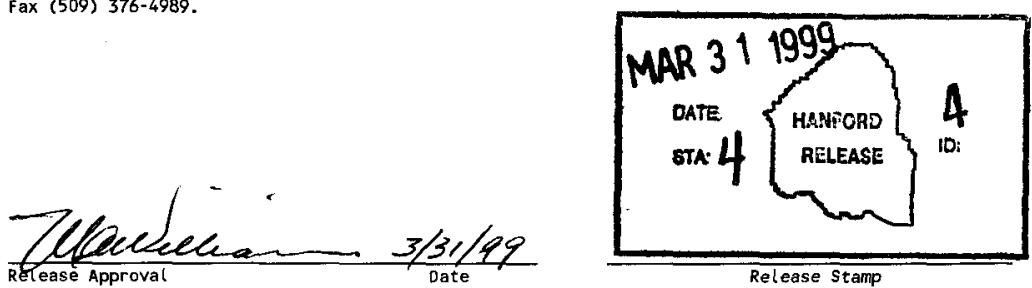

Approved for Public Release 
SNF-4238, Rev. 0

\section{TABLE OF CONTENTS}

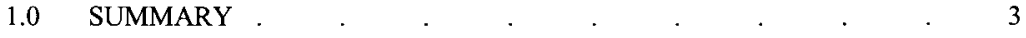

2.0 STATEMENT OF ISSUE . . . . . . . . . . 3

3.0 BASIS OF CLOSURE $\quad$. $\quad$. . . . . . 3

4.0 DISCUSSION. $\quad . \quad$. $\quad . \quad$. $\quad . \quad$. 44

5.0 REFERENCES . . . . . . . . . . 7 


\section{Issue Closure Package}

\section{Issue: Uranium Oxidation Rates}

Lead:

R. A. Sexton

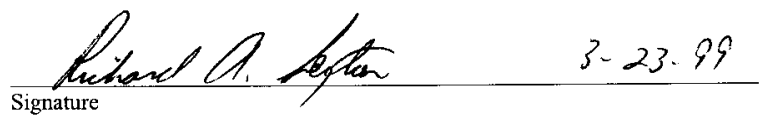

\section{Approvals:}

Chief Engineer: fou W. C. Miller

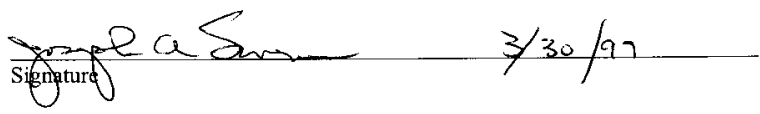

Technical Operations:

J. A. Swenson

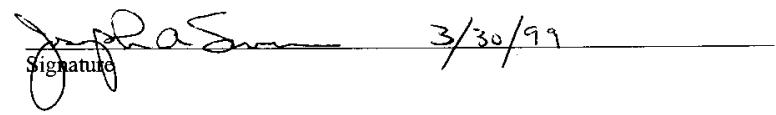

Process Engineering:

J. R. Frederickson

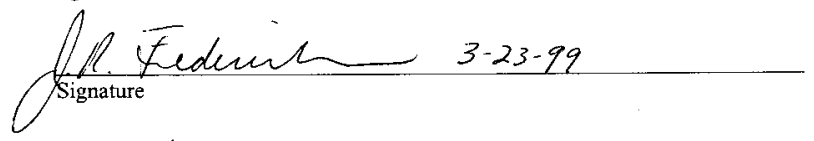

Nuclear Safety:

R. G. Morgan

MCO Design Authority:

L. H. Goldmann

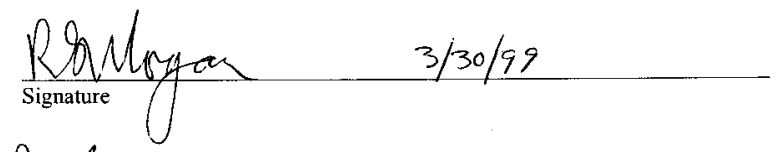
gurs Heldmom 3129199

Signature

SNF Characterization Project

D. W. Bergmann

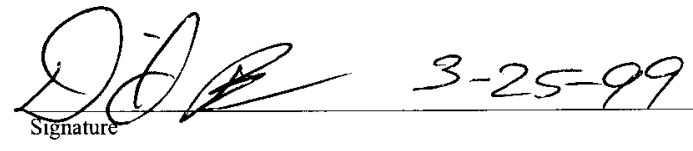




\subsection{Summary}

An assessment of all relevant uranium reaction rate data, including the most recently completed laboratory studies in moist inert gas, confirms that the correlations and enhancement factor already documented in the SNF Project Technical Databook (Reilly, 1998) are appropriately conservative.

Uranium reaction rate data from studies of spent $\mathrm{N}$ reactor fuel were used to confirm reaction rate correlations which were derived from literature data and used in system design for the Spent Nuclear Fuel (SNF) Project. A rate enhancement factor is used with these correlations to account for uncertainty associated with the data and the potential for spent $\mathrm{N}$ Reactor fuel having characteristics that differ from uranium represented in the literature data.

\subsection{Statement of the Issue}

Uranium oxidation rates under the varying conditions in the MCO are important in modeling heat generation, gas composition, and particulate generation in the $\mathrm{MCO}$. These reaction rates are used in SNF Project safety basis calculations.

The SNF Project processes and systems have been developed using data available in the technical literature, with a rate enhancement factor to conservatively account for the uncertainties in these data and the potential for spent $\mathrm{N}$ Reactor fuel having characteristics that differ from uranium represented in the literature data.

Confirmatory reaction rate data for spent $\mathrm{N}$ Reactor fuel were required to substantiate the reaction rates used in the project basis. The most recent data to be obtained by the SNF Characterization Program were reaction rates in moist inert gas. These data were needed to provide a complete basis for issue closure.

\subsection{Basis of Closure}

The SNF Project understanding of uranium oxidation rates now rests on literature data confirmed by reaction rate data for $\mathrm{N}$ Reactor fuel from the following sources:

- Laboratory studies on small N Reactor fuel samples designed to confirm reaction rates (Trimble, 1999):

- In dry air at high temperature $\left(69^{\circ} \mathrm{C}\right.$ to $\left.275^{\circ} \mathrm{C}\right)$

- In moist air at high temperature $\left(198^{\circ} \mathrm{C}\right.$ to $\left.350^{\circ} \mathrm{C}\right)$

- In moist inert gas $\left(100^{\circ} \mathrm{C}\right.$ to $\left.211^{\circ} \mathrm{C}\right)$

- Hot cell studies that dried $\mathrm{N}$ Reactor fuel elements in moist inert gas, where rates can be inferred from isothermal periods at $50^{\circ} \mathrm{C}$ and $75^{\circ} \mathrm{C}$ (Lawrence, 1998)

- Fuel element shipping observations at approximately $20^{\circ} \mathrm{C}$, where gas generation rates were measured (Briggs and Roe, 1997, Attached as Appendix 10.1 to Pajunen, 1999) 
Assessment of all relevant reaction rate data has been documented in Pajunen, 1999 which confirms that the reaction rates currently used in SNF Project calculations are appropriately conservative. Peer review of Pajunen, 1999 was provided by Fauske and Associates.

Literature data correlations and a rate enhancement factor of 22 are documented in the Project Technical Databook (Reilly, 1998). The bulk of the data and analysis supports the use of an enhancement factor of 10 or less. No change is planned to the databook values at this time because no direct benefit would be derived from using a less conservative number and the change to the many approved calculations could create potential cost and schedule impacts to the project.

\subsection{Discussion}

Moist inert oxidation is the reaction of primary interest to the CVD safety basis. The recently completed moist inert laboratory tests are documented in Trimble, 1999. These tests produced good quality data that are consistent with literature data.

The moist inert tests used a disciplined experimental procedure with extensive equipment checkout and calibration. The testing included blank runs and unirradiated samples. There was extensive overview of the work, including a Data Integrity Review Team and executive overview (Swenson, 1999). The number of runs was statistically significant, with multiple runs at each temperature.

The moist inert data are well grouped, and uncertainty analysis confirms confidence that the data are consistent with literature data. The data points lie between the mean and lower bound of literature data. The tests produced no extreme values and no data showing significantly higher rates than the literature. The data from irradiated $\mathrm{N}$-fuel were similar to that from unirradiated samples.

Equipment sensitivity limited the minimum moist inert test temperature that could produce usable data to approximately $100^{\circ} \mathrm{C}$. At $75^{\circ} \mathrm{C}$, the low reaction rate did not produce data that could be used to determine a specific reaction rate, but the data confirm that oxidation rates at that temperature are bounded by literature rates. The overall temperature range for moist inert rate tests was $75^{\circ} \mathrm{C}$ to $211^{\circ} \mathrm{C}$.

Dry air reaction rate studies at relatively high temperature $\left(69^{\circ} \mathrm{C}\right.$ to $\left.275^{\circ} \mathrm{C}\right)$ were the initial focus of $\mathrm{N}$ Fuel tests, followed by moist air reaction rates in a similar temperature range (Abrefah, et al., 1998a and 1998b). These high temperature data were developed to support evaluation of accident scenarios in a hot conditioning process system. The hot conditioning process step was subsequently eliminated from the overall project, reducing the maximum temperature of interest part way through the experimental program.

Seventeen $\mathrm{N}$ Reactor fuel samples were tested in dry air at temperatures ranging from $69^{\circ} \mathrm{C}$ to $400^{\circ} \mathrm{C}$. Single data points at $69^{\circ} \mathrm{C}$ and $124^{\circ} \mathrm{C}$ indicate increased dry air oxidation rates for $\mathrm{N}$ Reactor fuel in comparison to literature data. These limited data do not provide a sufficient basis 
to conclude $\mathrm{N}$ Reactor fuel oxidation rates are faster than the uranium metal used in tests by other investigators. However, a sensitivity analysis (Pajunen, 1999, Attached as Appendix 10.2), specific to the SNF Project systems, concluded that the MCO is thermally stable for conditions encountered by the SNF process systems, even if the dry air oxidation rates were conservatively applied in project analyses. Also, air ingress accidents are limited by safety class design features. The dry air experiment uncertainty, therefore, does not impact SNF Project design or safety basis.

Single element drying test procedures also reflect the concept of performing hot conditioning steps, including a final heating of elements to $400^{\circ} \mathrm{C}$ (Lawrence, 1998). However, reaction rate data for the water vapor oxidation reaction can be inferred from isothermal periods in the drying experiment procedure, which occur at temperatures of $50^{\circ} \mathrm{C}$ and $75^{\circ} \mathrm{C}$.

All of the single element drying data at $50^{\circ} \mathrm{C}$ and most comparisons of the data at $75^{\circ} \mathrm{C}$ are bounded by literature data and an enhancement factor of 10 . When reaction rates from some of the data at $75^{\circ} \mathrm{C}$ are compared to the reaction of a bounding fuel basket, the rates approach but are bounded by literature data with an enhancement factor of 22 .

Fuel element shipping observations allow an estimate of liquid water oxidation reaction rates at approximately $20^{\circ} \mathrm{C}$ under real plant conditions (Pajunen, 1999, Attached as Appendix 10.1). Reaction rate predictions at these conditions, with an enhancement factor of 22 , were conservative by a factor of 10 when compared to shipping observations.

The uranium oxidation rate defines parameters important to the evaluation and design of fuel removal processes. A simplified description of the four major parameters defined by the uranium oxidation rate is as follows.

- Heat generation rate $=($ decay heat $)+($ heat of reaction $) \times($ oxidation rate $)$

- Hydrogen generation rate $=\left(\frac{\text { hydrogen produced }}{\text { uranium reacted }}\right) \times($ oxidation rate $)$

- Particulate generation $=($ oxidation rate $) \times($ time $)$

- Oxygen gettering rate $=\left(\frac{\text { oxygen reacted }}{\text { uranium reacted }}\right) \times($ oxidation rate $)$

Reilly, 1998 is the required reference for reaction rate correlations for SNFP design and evaluations. This databook relies on reviewed and approved reference studies as a basis for the reaction rate correlations presented for use in project design and includes correlations for all the uranium oxidation reactions applicable to the process systems.

Cooper, 1998 describes the oxidation reaction rate correlations identified for initial use in design studies. These correlations were selected from the relationships developed by investigators in the literature. Confirmatory experimental studies for selected reaction systems were performed to 
verify that $\mathrm{N}$ Reactor Fuel exhibits corrosion reaction rate characteristics similar to that of uranium metal samples used by studies reported in the literature.

More detailed summaries of the literature data available for the dry air, water vapor, and liquid water reactions were developed in Trimble, 1998a and Trimble, 1998b. These generally record the data available from literature reviews that formed the initial correlations presented in Cooper, 1998 and present regression analyses of the data.

Reaction rates have also been inferred by monitoring the rate of ${ }^{137} \mathrm{Cs}$ accumulation in $\mathrm{K}$ East Basin water treatment ion exchange columns (Johnson and Burke, 1995). While these data provide an indication of the total fuel reacted in the $\mathrm{K}$ East Basin, uncertainty as to whether the oxygenated or de-oxygenated water uranium oxidation reaction dominates the overall basin observations preclude use of these plant observations to confirm reaction rate correlations. 


\subsection{References}

Abrefah, J., H. C. Buchanan, W. M. Gerry, W. J. Gray, and S. C. Marschman, 1998a, Dry Air Oxidation Kinetics of K-Basin Spent Nuclear Fuel, PNNL-11786, Pacific Northwest National Laboratory, Richland, Washington.

Abrefah, J., H. C. Buchanan, and S. C. Marschman, 1998b, Oxidation Rate of K-Basin Spent Nuclear Fuel in Moist Air, PNNL-1 1844, Pacific Northwest National Laboratory, Richland, Washington.

Briggs, W. A., and N. R. Roe, 1997, Transmittal of the Monitoring Gas in 105-K West Basin Report, Internal Memo to R. P. Omberg dated May 2, 1997, DE\&S Hanford, Richland, Washington.

Cooper, T. D., 1998, Spent Nuclear Fuel Project Recommended Reaction Rate Constants for Corrosion of N-Reactor Fuel, HNF-SD-SNF-TI-020, Rev 2, DE\&S Hanford, Richland, Washington.

Johnson, A. B., Jr., and S. P. Burke, 1995, K Basin Corrosion Program Report, WHC-EP-0877, Westinghouse Hanford Company, Richland, Washington.

Lawrence, L. A., 1998, Drying Damaged $K$ West Fuel Elements (Summary of Whole Element Furnace Runs 1 through 8), HNF-3377, Rev 0, DE\&S Hanford, Richland, Washington.

Pajunen, A. L., 1999, Uranium Oxidation Rate Summary for the Spent Nuclear Fuel Project, HNF-4165, Rev. 0, DE\&S Hanford, Richland, WA

Reilly, M. A., 1998, Spent Nuclear Fuel Project Technical Databook, HNF-SD-SNF-TI-015, Rev 6, DE\&S Hanford, Richland, Washington.

Swenson, J. A., 1999, SNF TGA Executive Team Meeting and Teleconference, Meeting Minutes dated February 2, 1999, DE\&S Hanford, Richland, Washington.

Trimble, D. J., 1998a, Reaction Rate Constant for Dry Air Oxidation of K Basin Fuel, HNF-SD-SNF-CN-019, Rev 0, DE\&S Hanford, Richland, Washington.

Trimble, D. J., 1998b, Reaction Rate Constant for Uranium in Water and Water Vapor, HNF-2853, Rev 0, DE\&S Hanford, Richland, Washington.

Trimble, D. J., 1999, Oxidation Kinetics of K-Basin Fuel, HNF-4206, Rev 0, DE\&S Hanford, Richland, Washington. 